\title{
REQUIREMENTS FOR PHOTOGRAMMETRIC DATA COLLECTED IN NATIONAL GEODETIC AND CARTOGRAPHIC RESOURCE
}

\author{
W. Izdebski, A. Andrzejewski, A. Bober \\ Head Office of Geodesy and Cartography, Warsaw, Poland \\ (waldemar.izdebski, adam.andrzejewski, anna.bober)@gugik.gov.pl
}

Commission I, WG I/10

KEY WORDS: national geodetic and cartographic resource in Poland, photogrammetric data, data quality control

\begin{abstract}
:
The Registers of the national geodetic and cartographic resources deliver reference information for other resources of Spatial Data Infrastructure (SDI). It is essential that the good quality information from public resources has a direct impact on the correctness of the conducted processes and analysis of public and private sectors. Besides knowledge about quality of data is crucial for users to compare datasets to determine which best fulfils for their needs. Therefore requirements for data are a vital to the process of selecting a data set in that the value of data are directly related to its quality. This paper presents concept of Polish Registers for photogrammetric data: technical standards for aerial imagery, elevation data, ortophotomaps, among others completeness, accuracy and spatial characteristics. In addition, article presents current state of the photogrammetric data in the Polish Geodetic and Cartographic Resource.
\end{abstract}

\section{INTRODUCTION TO PHOTOGRAMMETRIC REGISTERS}

The basic requirements for photogrammetric data are defined in The Geodetic and Cartographic Law (Polish Parliament, 1989), Regulation regarding databases on aerial and satellite imagery, orthophotomap and a digital terrain model (Ministry of Interior and Administration, 2010) and Regulation regarding the National Spatial Reference System (Councils of Ministers, 2011). More detailed requirements are described in technical standards for the tender.

The national geodetic and cartographic resource in Poland is divided into three groups of geodetic and cartographic documentation: the central resource, voivodeship resources and district resources. The central resource is provided by Head Surveyor of the Country and contain data sets and databases of spatial data infrastructure including photogrammetric data: aerial and satellite images, orthophotomaps and digital terrain models. All registers include metadata describing them and the services they perform in accordance with the Act on Spatial Information Infrastructure (Polish Parliament, 2010). The data stored in national geodetic and cartographic resource in Poland are published in the national broker: www.geoportal.gov.pl. The web application lets browse and search spatial data sets and services which belong to the National Spatial Data Infrastructure. Besides, Head Office of Geodesy and Cartography provides web services, such as view services (WMS, WMTS), discovery services (CSW) and download services (WFS, ATOM, WCS). These allow web clients to query and receive spatial data in the form of image, vector or coverage data.

The following photogrammetric information is verified and collected in the national geodetic and cartographic resource:

- in the register of aerial and satellite images:

- data sets of aerial and satellite imagery,

- $\quad$ flight parameters, such as the type of aircraft, helicopter or name of the satellite, date of the flight, flight altitude, place and time of flight, meteorological conditions: cloudiness, visibility, fog, turbulence, drift angle, azimuth

- technical parameters of the camera

- data specifying the spatial location of the analog measuring camera,

- $\quad$ angles $\omega, \varphi, \kappa$

- metadata

in the register of ortophotomaps:

- data sets of orthophotomaps

- metadata

in the register of digital terrain model:

- $\quad$ LIDAR data

- Points (mass, characteristic and height) and lines (structural, contour lines, closed lines describing planar areas, closed lines describing areas excluded from measurements) obtained by photogrammetric methods

- Digital elevation model

- Digital surface model

- Metadata

The Head Office of Geodesy and Cartography use this law regulations and specifications to acquire photogrammetric data and to create consistency across all data and partner-funded photogrammetric collections from public fund. Local conditions and application in any given project, or the preferences of partners may mandate more stringent requirements. In these cases, the Head Office of Geodesy and Cartography support or encourage to the collection of more detailed, accurate, or valueadded data. Local conditions may also prevent a given collection from meeting these specifications (for example writing format). 


\section{REQUIREMENTS FOR PHOTOGRAMMETRIC DATA COLLECTED IN NATIONAL GEODETIC AND CARTOGRAPHIC RESOURCE}

\subsection{Quality of photogrammetric data in other countries}

Information about quality of spatial data allows a data producer to evaluate how well a data set meets the criteria set forth in its product specification and assist data users in evaluating a product's ability to satisfy the requirements for their particular application (ISO19157:2013). Therefore it was very important to prepare quality control model for aerial imagery, orthophotomaps and elevation data, including requirements stemming from legal regulations and technical standards, such as correctness, consistency and accuracy. It is essential that data into national geodetic and cartographic resource has defined standard.

In comparison to other countries the basic difference in photogrammetric data is current horizontal and vertical coordinate systems and spatial characteristic (comparing to current technical specification for Great Britain, TexasStatement of Work for the Acquisition and Production of High Resolution Orthoimagery in Texas,2019, Virginia- Digital Orthoimagery Base Specification V1.0, 2014). Photogrammetric data in polish resource are defined in plane rectangular coordinates PL-1992 (for topographic scale) and PL-2000 (for large scale), that use Gauss-Krüger projection to implement a one-zone system with a $19^{\circ}$ meridian axial (PL-1992) and the realization of a four-zone system (with a width of $3^{\circ} \mathrm{each}$ ) with $15^{\circ}, 18^{\circ}, 21^{\circ}$ and $24^{\circ}$ meridians axial (PL-2000). In the case of vertical reference frames, vertical reference frames are marked by symbols PL-KRON86-NH and PL-EVRF2007-NH, which are the mathematical and physical implementation of the European Vertical Reference System (EVRS). The vertical reference frame PL-KRON86-NH is associated with the tide-gauge in Kronstadt, PL-EVRF2007-NH is associated with the tide-gauge in Amsterdam.

In case of technical parameters, Poland is in the top of European countries in the field of LIDAR data. Density 12 points $/ \mathrm{m}^{2}$ for cities, 4 points $/ \mathrm{m}^{2}$ for other areas and accuracy (xy: $15 \mathrm{~cm}-20 \mathrm{~cm}$, $\mathrm{z}: 20 \mathrm{~cm}$ ) of LIDAR data is one of the best in Europe: Sweden - 2 points $/ \mathrm{m}^{2}$, Westfalia $>4$ points $/ \mathrm{m}^{2}$, Netherlands $>8$ points $/ \mathrm{m}^{2}$ (Vosselman, 2018). Aerial photography and orthophotomaps are very similar to other European countries (RGB/CIR, pixel size 3$10 \mathrm{~cm}$ for cities and $10-25 \mathrm{~cm}$ for other areas).

What is very important data specifications mostly do not define the methodology and technology of processing, they define only final products.

\subsection{Basic requirements for aerial imagery}

Quality criteria of aerial imagery for polish resource are similar to another countries in Europe. The difference are mainly connected with writing format. Aerial imagery in polish resource must be written with following parameters:

\begin{tabular}{|l|l|}
\hline Color & RGB/CIR \\
\hline Format & Tiff \\
\hline Radiometric resolution & 8 bit/band \\
\hline Overview & Gaussian method \\
\hline Compression & JPEG, $Q=4 / Q=5$ \\
\hline
\end{tabular}

Table 1. Aerial imagery- parameters of writing

Other requirements for photogrammetric imagery are similar to other European countries:
1. Overlap shall be sufficient to provide full stereoscopic coverage of the areas to be photographed. Endlap shall average not less than sixty percent $(60 \%)$. Sidelap shall average not less twenty-five- thirty percent (25-30\%),

2. Aerial photography shall not be undertaken when the sun angle is less than twenty (20-30) degrees above the horizon.

3. Each camera shall have been calibrated, tested, and certified. In practice, current legal regulation allow only large format cameras.

4. The axis of the camera should be in a vertical position. The tilt (departure from the vertical) should not exceed four degrees $\left(3^{\circ}\right)$ or the relative tilt between images or strips exceed six degree $\left(5^{\circ}\right)$

5. Aerial photography shall not be taken when the ground is obscured by haze, snow, foliage, flooding conditions or when clouds or cloud shadows.

6. Photography shall be executed so as to minimize image movement at the moment of exposure.

7. It's necessary to use GCP.

GSD depends on area of aerial photography and on application. Nowadays, normally for cities/counties the standard is $3-10 \mathrm{~cm}$, for other areas $10-25 \mathrm{~cm}$

The most common reason for aerial imagery rejection is fuzzy imagery caused by image movement at the moment of exposure. Sometimes imagery are not correct geometrically (values of $\omega, \varphi$, $\kappa$ are exceed allowed values $3,3,15$ degree).

\subsection{Basic requirements for orthophotomaps}

Orthophotomaps in national geodetic and cartographic resource must meet the following criteria:

\begin{tabular}{|l|l|}
\hline Colour & RGB/CIR \\
\hline Format & GeoTiff \\
\hline Radiometric resolution & 8 bit/band \\
\hline Overview & Gaussian method \\
\hline Compression & JPEG, $\mathrm{Q}=4 / \mathrm{Q}=5$ \\
\hline orthorectification & Bilinear/bicubic \\
\hline RMSExy & $<=3$ pixel size \\
\hline
\end{tabular}

Table 2. Orthophotomaps- parameters of writing Besides:

1. Orthophotomaps must be created from stereoscopic aerial imagery collected in national geodetic and cartographic resource.

2. Orthophotomas must be geometrically correct, without errors caused by wrong Digital Elevation Model or wrong aerotriangulation.

3. Aerotriangulation (AT) used in the orthorectification process, shall consist of a minimum of exterior orientation parameters, refined image coordinates and adjusted ground coordinates.

4. Orthoimagery must be free from errors connected with image mosaicking. Specular reflections and other artifacts should be minimized, especially in developed areas. Above ground features appearing in the orthoimage imagery, such as building roof tops, towers, shall not be clipped at seamlines or between individual image files.

5. Elevation data used during the orthorectification process shall have sufficient resolution and density to produce orthoimagery that meets the horizontal accuracy requirements. 
The most common reason for orthophotomaps rejection are geometrical errors caused by wrong Digital Elevation Model, sometimes there are defects connected with wrong image mosaicking.

Pixel size of orthophotomaps depends on area and on application. Normally for cities/counties the standard is $3-10 \mathrm{~cm}$, for other areas $10-25 \mathrm{~cm}$. Nowadays cover of Poland of $25 \mathrm{~cm}$ orthophotomaps takes place in 3-years cycle, $10 \mathrm{~cm}$ and better (cities/counties) in 5-years cycle.

The figure figure 1 presents actual state of the latest orthophotomaps, figure 2 presents planed state of $25 \mathrm{~cm}$ orthophotomaps in national resource on the end of 2019 year, figure 3 presents planed state of $10 \mathrm{~cm}$ orhophotomaps on the end of 2019 year, and figure 4 presents planned state of all orthophotomaps on the end of 2019 year:

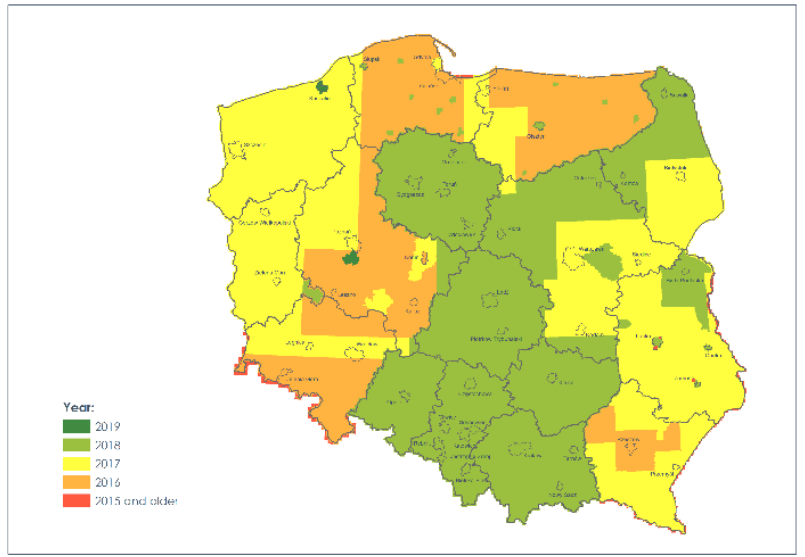

The figure 1. Actual state of latest orthophotomaps in national resource, state on the July 2019

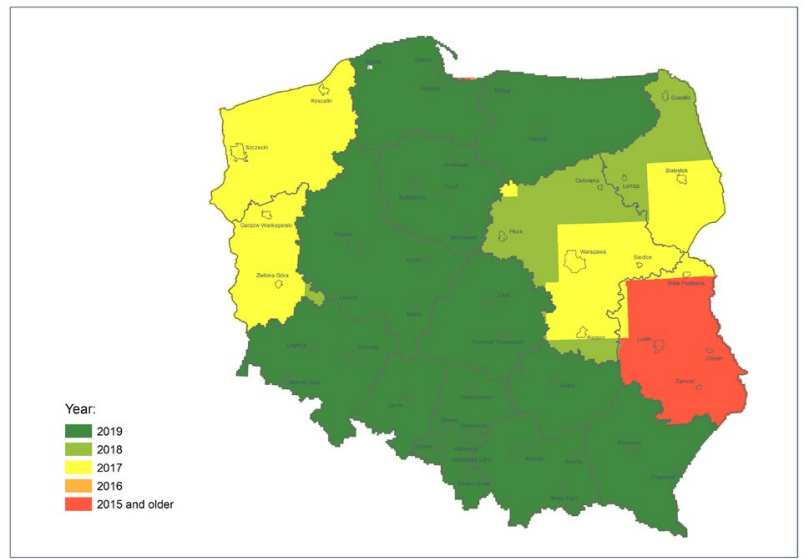

The figure 2. Planed state of $25 \mathrm{~cm}$ orthophotomaps in national resource on the end of 2019 year

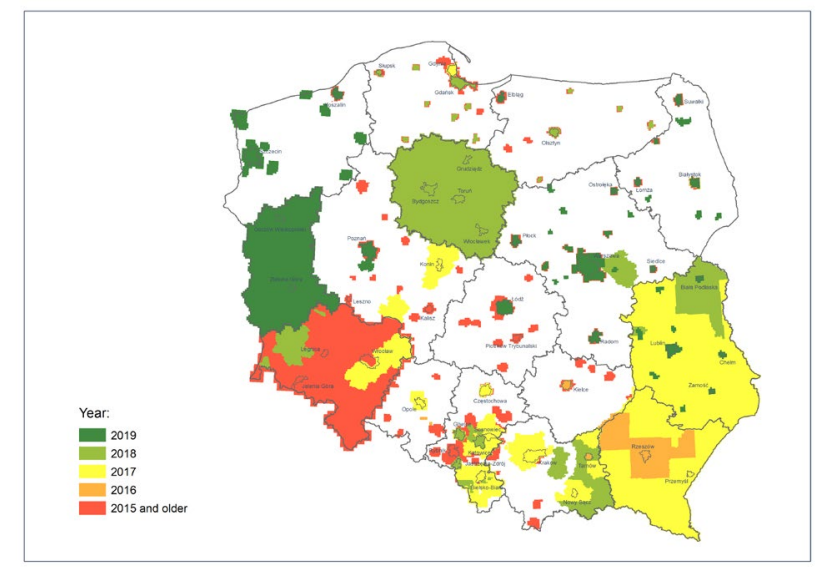

The figure 3. Planed state of $10 \mathrm{~cm}$ orthophotomaps in national resource on the end of 2019 year

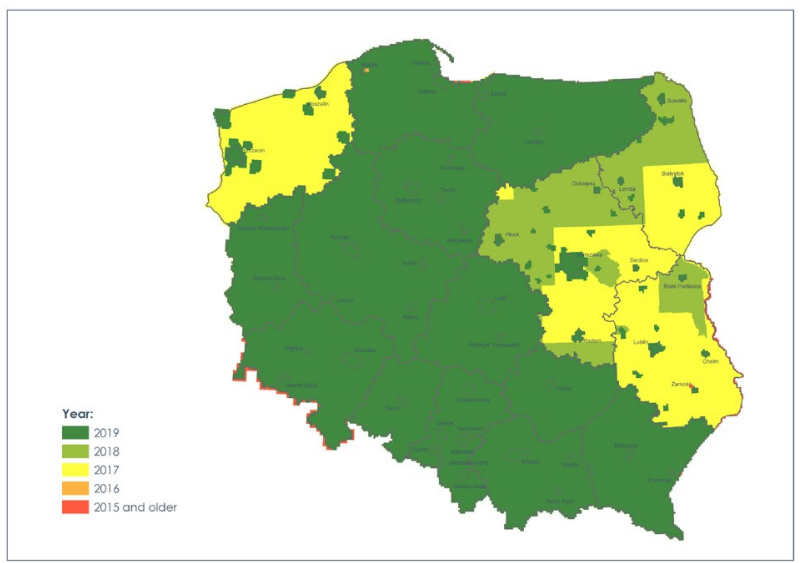

The figure 4. Planned state of orthophotomaps in national resource on the finish of 2019 year.

\subsection{Basic requirements for LIDAR DATA}

LIDAR data for national geodetic and cartographic resource must meet the following criteria:

\begin{tabular}{|l|l|}
\hline Absolute vertical accuracy & $<=15 \mathrm{~cm}$ \\
\hline Absolute horizontal accuracy & $<=30 \mathrm{~cm}$ \\
\hline Relative vertical accuracy & $<=8 \mathrm{~cm}$ \\
\hline Relative horizontal accuracy & $<=20 \mathrm{~cm}$ \\
\hline LIDAR density & $\begin{array}{l}12 \mathrm{p} / \mathrm{m} 2 \text { for cities; } 4 \mathrm{p} / \mathrm{m} 2 \\
\text { for other areas }\end{array}$ \\
\hline Format & $\begin{array}{l}\text { LAS, version } 1.2, \text { POINT } \\
\text { DATA RECORD } \\
\text { FORMAT 3. }\end{array}$ \\
\hline Classification & $\begin{array}{l}\text { ASPRS Standard LiDAR } \\
\text { Point Classes }\end{array}$ \\
\hline
\end{tabular}

Table 3. LIDAR data- parameters of writing

Besides:

1. Scan angles $> \pm 25$ are not allowed

2. Registration of a minimum four "echoes" is required.

3. It is required to register the intensity of the reflected signals

4. The average distance of the LIDAR points in the flight direction and in the transverse direction ranged from 1 : 1.5 to $1.5: 1$

5. LIDAR data should be classified: 0 - Created, never classed, 2- Ground, 3- Low vegetation, 4- Medium 
Vegetation, 5- High vegetation, 6- Building, 7- Low points (noise), 9- Water, Overlap points.

6. $99 \%$ LIDAR points must be correctly classified to ground class

7. $95 \%$ LIDAR points must be correctly classified to class used to generation digital surface model.

8.

The most common reason for LIDAR rejection are errors caused by wrong classification and incorrect header of LAS files.

Density of Lidar points depends on area and on application. Normally for cities/counties the standard is $12 \mathrm{p} / \mathrm{m} 2$, for other areas $4 \mathrm{p} / \mathrm{m} 2$. Cover of Poland of LIDAR data is planned in 6years cycle.

The figure 5 below presents actual state LIDAR data in national resource, figure 6 presents planned state on the finish of 2019 year:

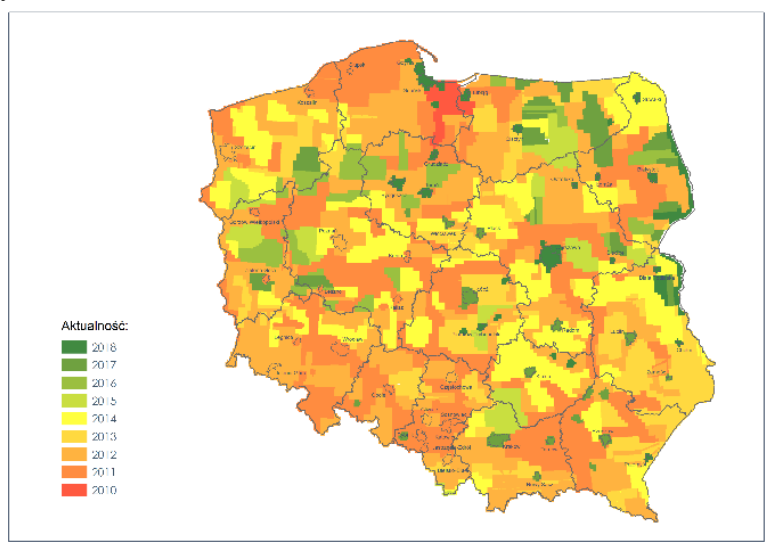

Figure 5 Actual state LIDAR data in national resource

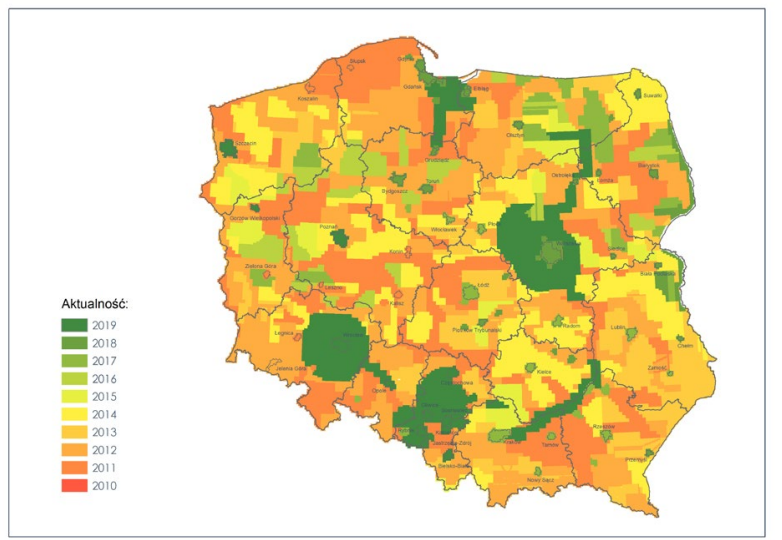

Figure 6 Actual state LIDAR data in national resource

\section{PHOTOGRAMMETRIC DATA AS A PART OF NATIONAL SPATIAL DATA INFRASTRUCTURE}

The term of Spatial Data Infrastructure SDI was introduced by U.S. Vice President Al Gore and propagated by international organisations such as FIG or ISPRS (Konecny, 2005). SDI fundamentally means facilitation and coordination of the exchange and sharing of spatial data between stakeholders from different jurisdictional levels in the spatial data community (Williamson, Rajabifard, 2003). Therefore, in the national context, develop and success of a SDI depends mainly on the availability of data. The key components of SDI are geoportal (most visible part of SDI), metadata and search functions $(\mathrm{Hu}, \mathrm{Li}$, 2017). According to art. 13 section 2 of the Law of 4 March 2010.
Spatial data infrastructure "'Surveyor General for Poland establishes and maintains publicly available register of spatial datasets and services covered by the spatial data infrastructure and gives them uniform identifiers." and Regulation of the Minister of Investment and Development of 28 November 2018 amending the regulation on the registration of spatial data sets and services covered by the spatial information infrastructure. "The register are kept in the IT system whose database is integrated with the geoportal of the spatial information infrastructure, referred to in article 13 section 1 of the Act of 4 March 2010 on Spatial Data Infrastructure" the register of spatial data sets was made available.

Figures bellow shows register of orthophotomaps (Figure 7) and elevation (Figure 8):

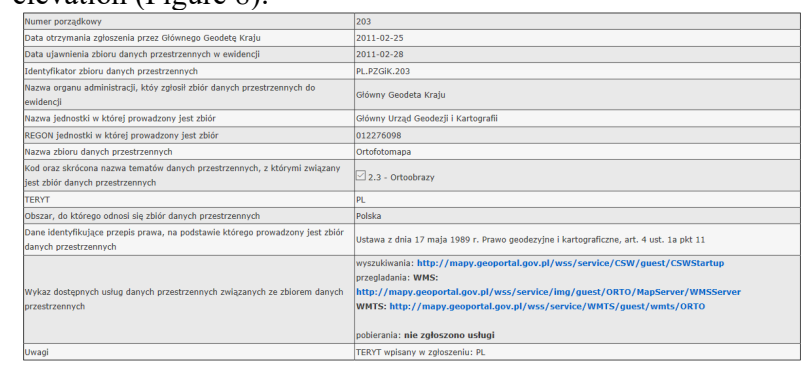

Figure 7. National register of orthophotomaps https://integracja.gugik.gov.pl/eziudp/index.php?edycja=16358

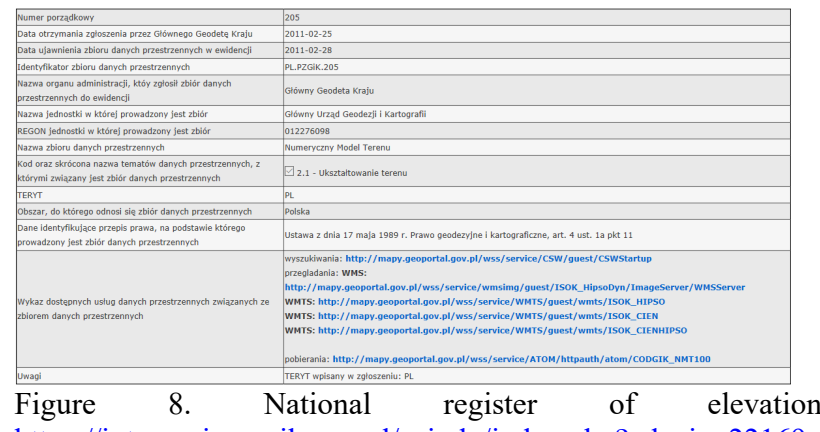

https://integracja.gugik.gov.pl/eziudp/index.php?edycja=22169

Head Office of Geodesy and Cartography in Poland provided services of photogrammetric data sets: WMS, WMTS, CSW, WFS, ATOM, WCS. It can be integrated into any mapping application for web application allowing for an easy-to-use way to exploit the data. The table 4 presents provided web services for photogrammetric data.

\begin{tabular}{|c|c|}
\hline WMS & $\begin{array}{l}\text { • Orthophotomap } \\
\text { http://mapy.geoportal.gov.pl/wss/service/img/guest/ORTO/Ma } \\
\text { pServer/WMSServer } \\
\bullet \quad \text { Orthophotomap - archival } \\
\text { http://mapy.geoportal.gov.pl/wss/service/img/guest/ORTO_TI } \\
\text { ME/MapServer/WMSServer } \\
\bullet \quad \text { Digital Elevation Model ISOK - Hipsometry } \\
\text { http://mapy.geoportal.gov.pl/wss/service/wmsimg/guest/ISOK_ } \\
\text { HipsoDyn/ImageServer/WMSServer } \\
\bullet \quad \text { Digital Elevation Model LPIS - Hillshade } \\
\text { http://mapy.geoportal.gov.pl/wss/service/img/guest/CIEN/Map } \\
\text { Server/WMSServer } \\
\text { • Digital Elevation Model LPIS - Hipsometry } \\
\text { http://mapy.geoportal.gov.pl/wss/service/img/guest/HIPSO/ } \\
\text { MapServer/WMSServer } \\
\text { • Aerial photography - indexes } \\
\text { http://mapy.geoportal.gov.pl/wss/service/pub/guest/G2_SKOR } \\
\text { OWIDZE_ZDJECIA/MapServer/WMSServer }\end{array}$ \\
\hline WMTS & $\begin{array}{l}\bullet \quad \text { Digital Elevation Model ISOK - Hipsometry } \\
\text { http://mapy.geoportal.gov.pl/wss/service/WMTS/guest/wmts/I } \\
\text { SOK_HIPSO } \\
\bullet \quad \text { Digital Elevation Model ISOK- Hillshade }\end{array}$ \\
\hline
\end{tabular}




\begin{tabular}{|c|c|}
\hline & $\begin{array}{l}\text { http://mapy.geoportal.gov.pl/wss/service/WMTS/guest/wmts/I } \\
\text { SOK_CIEN } \\
\text { - Digital Elevation Model ISOK - Hillshade and } \\
\text { Hipsometry } \\
\text { http://mapy.geoportal.gov.pl/wss/service/WMTS/guest/wmts/I } \\
\text { SOK_CIENHIPSO } \\
\text { http://mapy.geoportal.gov.pl/wss/service/WMTS/guest/wmts/H } \\
\text { IPSO Digo } \\
\text { - Digital Elevation Model LPIS - Hillshade } \\
\text { http://mapy.geoportal.gov.pl/wss/service/WMTS/guest/wmts/C } \\
\text { IEN - Orthophotomap } \\
\text { http://mapy.geoportal.gov.pl/wss/service/WMTS/guest/wmts/O } \\
\text { RTO }\end{array}$ \\
\hline CSW & $\begin{array}{l}\text { • Katalog Metadanych - krajowy } \\
\text { http://mapy.geoportal.gov.pl/wss/service/CSW/guest/CSWStart } \\
\text { up }\end{array}$ \\
\hline WFS & $\begin{array}{l}\text { • Digital Elevation Model } \\
\text { http://mapy.geoportal.gov.pl/wss/service/img/httpauth/NMT/M } \\
\text { apServer/WFSServer } \\
\text { • Indexes } \\
\text { http://mapy.geoportal.gov.pl/wss//service/pub/httpauth/G2_skor } \\
\text { owidze WFS/MapServer/WFSServer }\end{array}$ \\
\hline ATOM & $\begin{array}{l}\text { • NMT_100 - Digital Elevation Model }(100 \mathrm{~m}) \\
\text { http://mapy.geoportal.gov.pl/wss/service/ATOM/httpauth/atom } \\
\text { /CODGIK_NMT100 }\end{array}$ \\
\hline WCS & $\begin{array}{l}\text { • Hipsometria } \\
\text { http:/mapy.geoportal.gov.pl/wss/service/img/guest/HIPSO/Ma } \\
\text { pServer/WCSServer } \\
\text { • Ortofotomapa } \\
\text { http://mapy.geoportal.gov.pl/wss/service/img/guest/ORTO/Ma } \\
\text { pServer/WCSServer } \\
\text { • Cieniowanie } \\
\text { http://mapy.geoportal.gov.pl/wss/service/img/guest/CIEN/Map } \\
\text { Server/WCSServer }\end{array}$ \\
\hline
\end{tabular}

Table 4. Web services for photogrammetric data provided by Head Office of Geodesy and Cartography

Furthermore, national photogrammetric data sets are published in the national broker: www.geoportal.gov.pl. The web application lets browse and search spatial data sets and services for aerial imagery, orthophotomaps and elevation data.

The figure below shows user interface of national geoportal with loaded orthophotmaps and indexes:

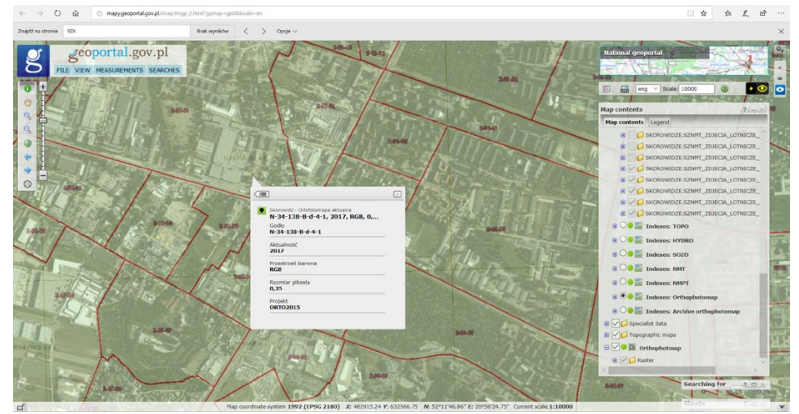

Figure 7. Screenshot of Polish geoportal presenting orthophotomaps.

What is very important, photogrammetric data and services are important part of national Spatial Data Infrastructure and deliver reference information for other resources. For example, LIDAR data was reference data for $3 \mathrm{~d}$ building models- CityGML LOD1 (almost 9 million buildings) and LOD2 (above 10 million buildings) created by Head Office of Geodesy and Cartography. The model buildings, published by ATOM service, are very popular among users. The present number of downloads city model buildings is about 22016, what is success of national SDI. Figure 8 presents $3 \mathrm{~d}$ model buildings- LOD1 for Poland:

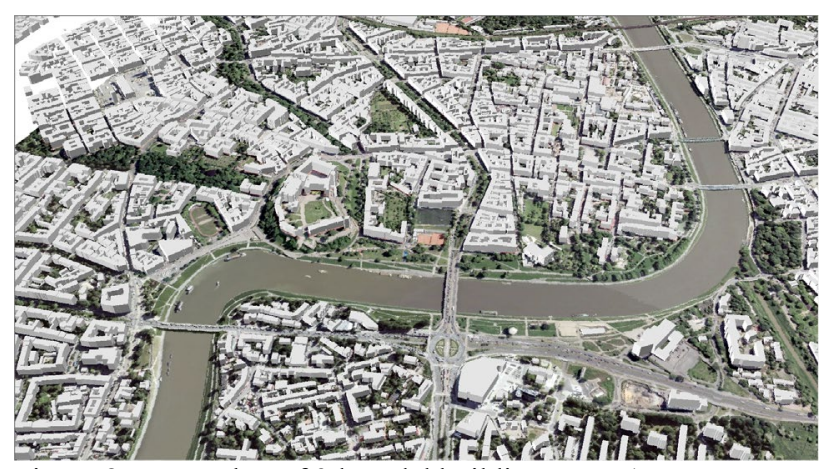

Figure 8. Screenshot of 3d model building- LOD1.

\section{CONCLUSIONS}

Requirements for aerial imagery, orthophotomaps and elevation data are necessary to ensure consistency of national photogrammetric resource. Polish requirements for photogrammetric data are very similar to European standards.

Photogrammetric data and services are important part of national Spatial Data Infrastructure and deliver reference information for other resources. Furthermore develop and success of national SDI depends mainly on the availability of data.

\section{REFERENCES}

Act of Polish Parliament, 1989, The geodetic and cartographic law, Warsaw

Act of Polish Parliament, 2010, Spatial Information Infrastructure, Warsaw

Regulation of Minister of Interior and Administration regarding databases on passenger and service images as well as an orthophotomap and a digital terrain model, Warsaw, 2010 PN-EN ISO 19157 Geographic information - Data quality Regulation of Councils of Ministers Regarding the National Spatial Reference System, Warsaw, 2011

Regulation of the Minister of Investment and Development amending the regulation on the registration of spatial data sets and services covered by the spatial information infrastructure, Warsaw, 2018

Great Britain- specification for spatial data: https://www.ordnancesurvey.co.uk/

Statement of Work for the Acquisition and Production of High Resolution Orthoimagery in Texas v9, https://tnris.org/static/documents/stratmap/tx_orthoimagery_so w_v9.pdf

Rufe, P., P., 2014, Digital Orthoimagery Base Specification V1.0, https://pubs.usgs.gov/tm/11/b5/pdf/tm11-B5.pdf

Konecny, G., 2005, The cadastre as part of a spatial data infrastructure for developing countries, E/CONF.96/I.P.21, https://unstats.un.org/unsd/geoinfo//RCC/docs/rcca8/IP/8th_UN RCCA_econf.96_IP21.pdf

Williamson, I., P., Rajabifard, A., 2003, Spatial data infrastructures: concept, SDI hierarchy and future directions, https://www.researchgate.net/publication/228581533_Spatial_d ata_infrastructures_concept_SDI_hierarchy_and_future_directio ns 
Hu, Y., and Li, W. (2017). Spatial Data Infrastructures. The Geographic Information Science \& Technology Body of Knowledge (2nd Quarter 2017 Edition), John P. Wilson (ed.). DOI: $10.22224 /$ gistbok/2017.2.1
Vosselman, G., (2018) Point clouds and derivatatives for nationwide geospatial information, https://www.isprs.org/tc2symposium 2018 